\title{
DOES DEFAULT RISK MATTER FOR INVESTORS IN REITs
}

\author{
Yezhou SHA ${ }^{1}$, Zilong WANG ${ }^{2}$, Ziwen BU ${ }^{3}$, Nick MANSLEY ${ }^{2}$ \\ ${ }^{1}$ School of Finance, Capital University of Economics and Business, Beijing, China \\ ${ }^{2}$ Department of Land Economy, University of Cambridge, Cambridge, UK \\ ${ }^{3}$ Department of Finance, University of Birmingham, Birmingham, UK
}

Received 08 October 2019; accepted 02 April 2020

\begin{abstract}
We investigate the relationship between default risk and REIT stock returns. A default risk long-short investment strategy generates a return of $15 \%$ per annum. We also evaluate a large number of potential explanations for the negative relationship between default risk and subsequent stock returns. We do not find robust evidence that the default risk premium can be explained by firm size, book-to-market equity, asset growth and idiosyncratic volatility. However, CAPM beta shows some promise in explaining the default risk premium. Our results shed further light on the role of default risk in investment in REITs.
\end{abstract}

Keywords: default risk, Real Estate Investment Trust (REIT), anomalies, distress puzzle, cross-sectional return, real estate investment.

\section{Introduction}

Real Estate Investment Trusts (REITs) were firstly introduced in the United States in 1960, and they provide a liquid way for investors to gain real estate exposure. The United States. has the largest REITs market with a market capitalisation of 1.05 trillion US dollars in 2018 accounting for around $60 \%$ of the $\$ 1.7$ trillion global REIT universe. REITs experienced a sharp fall in values in the Global Financial Crisis (GFC) between 2007 and 2009, the National Association of Real Estate Investment Trusts (NAREIT) index fell 67\% (Sun et al., 2015). However, the loss is subsequently and gradually recovered after the financial crisis. Sun et al. (2015) explain the phenomenon as the over-reaction to default risk during the GFC. Chung et al. (2016) argue that REITs are particularly exposed to high default risk during periods of financial market turmoil. This is because REITs typically have high leverage ratios and low cash holdings. When capital markets dry up, REITs may therefore be constrained to pay down debt. Some REITs eventually file for bankruptcy, default and delist due to business failure (see Appendix A for details). These cases are, as one would expect concentrated in periods of economic recession and financial crisis. However, REITs generate relatively stable cash flows and are predominantly comprised of tangible assets that have high recovery rates, implying that the actual extent of loss from default may be less than for the average public company.

Although defaults by REITs are rare, concern about the risk of default could still drive significant changes in the stock price, this raises the question of whether default risk matters for investors in REITs and if and how default risk is priced into REITs. By sorting REITs into portfolios on default risk, we find a long-short portfolio holding REITs with the lowest default risk and short selling REITs with the highest default risk would have generated a return of $15 \%$ per annum, suggesting a default risk premium exists in the US REITs market. To investigate the default risk premium in REITs, this paper examines the drivers of the default risk premium to help understand whether using default risk is a practical investment strategy.

Our paper makes a number of contributions to the literature. Firstly, to our knowledge, this is the first study to comprehensively investigate REIT's default risk. Secondly, we find robust evidence that there is a significant default risk premium among REITs. A default risk investment strategy (long low default risk REITs and short high default risk REITs) generates a return of $15 \%$ per annum or a risk-adjusted return around 20\% per annum. The returns from a default risk premium strategy are greater than those for other REIT return strategies identified in the literature such as momentum (Hao et al., 2016), idiosyncratic

*Corresponding author. E-mail: zw325@cam.ac.uk 
volatility (Ooi et al., 2009; Cakici et al., 2014), or asset growth (Ling et al., 2019). Thirdly, we investigate the effects of various factors which potentially affect the relationship between default risk and REITs returns, and we do not find evidence that the default risk premium can be significantly explained by firm size, book-to-market equity ratio, asset growth and idiosyncratic volatility. Finally, we find the general stock market CAPM beta appears to be a key driver of the default risk premium.

\section{Literature review}

Existing studies generally find a negative relationship between default risk and subsequent stock returns (see, among others, Dichev, 1998; Vassalou \& Xing, 2004; Campbell et al., 2008; Chava \& Purnanandam, 2010). The result contradicts the modern finance theory that investors require higher returns for bearing higher risk, this is called the "distress puzzle". Moreover, given the robust relationship between default risk and stock returns, Campbell et al. (2008) indicate that the default risk premium is monotonic and conjecture that the premium may exist in other asset classes. Subsequently, Zhang (2012) documents the existence of a default risk premium in both bond and credit default swap markets.

A key aspect of analysing default risk premium is improving the accuracy of measuring default risk. Hillegeist et al. (2004) find the probability of default calculated from an option pricing model has higher predictive power than conventional default risk measures such as O-score and $\mathrm{Z}$-score which are based on accounting information. A similar option pricing based approach is also developed by Vassalou and Xing (2004), which measures the distance of expected value of a firm's total assets to its default point and captures the default risk without requiring accurate estimation of default event distribution, this is called distance-to-default (DD). The DD measure is also investigated by Campbell et al. (2008) and Bharath and Shumway (2008). Additionally, Bharath and Shumway (2008) present a parsimonious solution to measure the DD, which uses the functional form suggested by Merton's (1974) model but does not solve the model for an implied probability of default. The search to determine the best measurement of default risk is still ongoing. For example, Charitou et al. (2013) propose an alternative estimate of default risk based on market-observable volatility which outperforms other estimates.

Given the importance and unique nature of REITs, the existing literature has explored the relations between REIT return and many risk factors such as leverage, debt structure, and return volatility (Sun et al., 2015; Kawaguchi et al., 2017; Cakici et al., 2014; Chung et al., 2016; Giacomini et al., 2015, 2017). Additionally, Anzinger et al. (2017) propose a quality factor for REITs which considers Altman (1968) Z-score as a component to quality attributes, with the emphasis on the effect of quality on REIT returns instead of analysing the relationship with default risk.
In the spirit of existing literature on discovering anomalies in REITs (see, among others, Anzinger et al., 2017; Cakici et al., 2014; Chung et al., 2016; DeLisle et al., 2013; Hao et al., 2016; Ling et al., 2019; Lin et al., 2009; Ooi et al., 2009), we measure the default risk of US REITs and investigate whether the risk is priced in or not. This study contributes to the growing literature on understanding default risk as well as highlighting a potential investment strategy for investors in REITs.

\section{Data and variables}

\subsection{Data}

We obtain daily stock price and monthly stock return data from the Center for Research in Security Prices (CRSP) and firm-specific accounting information from the Compustat Quarterly and Annual Industrial Files. Our preliminary sample comprises all public-traded US equity REITs that are listed on the NYSE, AMEX and NASDAQ exchanges. The classification of REITs follows Lin et al. (2009), using a SIC code of 6798 and a CRSP share code of 18 or 48. We also use the equity REITs list of Feng et al. (2011) as a source to enrich the sample size. Our sample period starts in January 1990 and ends in December 2016. The sample contains 502 unique REITs. The monthly and daily factors of market risk (MKT), size (SMB), value (HML), momentum (MOM), operating profitability (RMW), investment (CMA), and risk-free rate are obtained from Kenneth French's online Data Library. In line with Fama and French (1992), Campbell et al. (2008), and Bharath and Shumway (2008), we only keep equity REITs that have non-missing price and shares information at the end of the month before forming portfolios. We also drop any equity REIT that has a closing price below five dollars at the end of June to reduce the effect of penny stocks (Pástor \& Stambaugh, 2003; Kumar, 2009), since those excluded REITs are likely to be illiquid. To address the robustness of the sample, we report the results using the sample of all equity REITs and a sample dropping equity REITs with a price less than 1 dollar in Appendix C.

\subsection{Variables}

The default risk measure we adopt in this paper is the distance-to-default (DD) measure from Bharath and Shumway (2008), which is a simplified version of that introduced by Merton (1974). High DD implies low probability of default, which also implies low default risk. In detail, the DD defines the equity of firms as a call option on the underlying value of the firm with a strike price equal to the face value of the firm's debt with a defined time to maturity. The DD of firm $i$ is estimated as follows:

$$
D D_{i, t}=\frac{\log \left(\frac{\text { Equity }_{i, t}+D e b t_{i, t}}{\text { Debt }_{i, t}}\right)+\left(r_{i, t-1}-\frac{\sigma_{V i, t}^{2}}{2}\right) \times T}{\sigma_{V i, t}^{2} \times \sqrt{T}} ;(1)
$$

and 


$$
\begin{aligned}
& \sigma_{V i, t}=\frac{\text { Equity }_{i, t}+\text { Debt }_{i, t}}{\text { Debt }_{i, t}} \times \sigma_{E i, t}+ \\
& \frac{\text { Equity }_{i, t}+\text { Debt }_{i, t}}{\text { Debt }_{i, t}} \times\left(0.05+0.25 \times \sigma_{E i, t}\right)
\end{aligned},
$$

where: Equity $_{i, t}$ is the market value of equity (in millions of dollars) calculated as the number of shares outstanding times the price of the stock at the end of June of year $t ; D_{e b t}$ is the face value of debt computed as the sum of debt in current liabilities (Compustat item DLC) and one-half of long-term debt (Compustat item DLTT) at the end of June of year $t ; r_{i, t-1}$ is the past 12-month cumulative return; $\sigma_{E i, t}$ is the stock return volatility estimated using the monthly stock return from the past 12 -month; and $\sigma_{V i, t}$ calculated from $\sigma_{E i, t}$ is an approximation of the volatility of assets. We set $T$ to one year and construct $D D_{i, t}$ of all sample firms at the end of June of each year.

The DD uses market value of equity and volatility of assets to calculate the default risk of REITs. Alternative measures of default risk could be accounting based models. However, accounting based default risk measures typically use financial information including cash holdings and dividends which are not appropriate for REITs where dividend payout ratios are controlled by legislation and may therefore introduce biases. For a robustness check, we use another measure of default risk, failure probability, following Campbell et al. (2008). The method to construct failure probability is reported in Appendix B. The empirical results using failure probability as the default risk measure are reported in Appendix C.

We also calculate a number of additional variables for the empirical analysis. Equity REIT's size (ME) is measured by its market capitalization in million US dollars, the book-to-market ratio (BM) is based upon the definition in Fama and French (1993), asset growth rate (AG) follows the method in Cooper et al. (2008), idiosyncratic volatility relating to the FF3 (IVOL) is based upon the approach in Ang et al. (2006), and the CAPM beta for each individual stock is measured following Fama and French (2016). The detail of constructing the variables is reported in Appendix B. Table 1 reports summary descriptive statistics for DD and other variables. The descriptive statistics are calculated as the time-series averages of the cross-sectional summary statistics.

\begin{tabular}{|c|c|c|c|c|c|c|c|c|}
\hline \multicolumn{9}{|c|}{ Panel A: Summary statistics of variables } \\
\hline & $\mathrm{R}_{1,1}$ & $\mathrm{ME}$ & $\mathrm{BM}$ & $\mathrm{R}_{12,1}$ & $\mathrm{DD}$ & $\mathrm{AG}$ & IVOL & Beta \\
\hline Mean & 0.01 & 1851.52 & 0.76 & 0.12 & 8.28 & 0.20 & 0.07 & 0.65 \\
\hline Median & 0.01 & 968.88 & 0.68 & 0.11 & 7.63 & 0.08 & 0.06 & 0.58 \\
\hline Minimum & 0.24 & 4.66 & 9.52 & 0.55 & 1.89 & 0.60 & 0.03 & 0.52 \\
\hline Maximum & 0.30 & 23170.97 & 6.66 & 1.39 & 33.80 & 6.17 & 0.27 & 2.29 \\
\hline SD & 0.06 & 3153.12 & 1.50 & 0.24 & 5.51 & 0.63 & 0.04 & 0.43 \\
\hline Skewness & 0.61 & 2.66 & 1.76 & 0.69 & 1.47 & 4.28 & 2.91 & 0.74 \\
\hline \multicolumn{9}{|c|}{ Panel B: Correlation among variables } \\
\hline & $\mathrm{R}_{1,1}$ & $\mathrm{ME}$ & $\mathrm{BM}$ & $\mathrm{R}_{12,1}$ & DD & $\mathrm{AG}$ & IVOL & Beta \\
\hline $\mathrm{R}_{1,1}$ & 1 & & & & & & & \\
\hline $\mathrm{ME}$ & 0.01 & 1 & & & & & & \\
\hline $\mathrm{BM}$ & 0.02 & 0.17 & 1 & & & & & \\
\hline $\mathrm{R}_{12,1}$ & 0.08 & 0.10 & 0.12 & 1 & & & & \\
\hline $\mathrm{DD}$ & 0.11 & 0.29 & 0.23 & 0.30 & 1 & & & \\
\hline $\mathrm{AG}$ & 0.02 & 0.06 & 0.02 & 0.21 & 0.13 & 1 & & \\
\hline IVOL & 0.02 & 0.22 & 0.22 & 0.02 & 0.40 & 0.06 & 1 & \\
\hline Beta & 0.05 & 0.01 & 0.04 & 0.01 & 0.20 & 0.05 & 0.31 & 1 \\
\hline
\end{tabular}

Table 1. Descriptive statistics

Note: This table provides time-series averaged summary statistics and correlation of key attributes in this paper. $\mathrm{R}_{1 ; 1}$ is the REIT's monthly return. ME is the REIT's market capitalisation. BM is the book-to-market ratio. $\mathrm{R}_{12 ; 1}$ is the cumulative return in the past 12 months. DD is the distance-to-default following Bharath and Shumway (2008). AG is the ratio of asset growth rate. IVOL is the monthly idiosyncratic volatility relating to the Fama and French (1993) three-factor model. Beta is the 60-month rolling averaged CAPM beta. Appendix B provides the definitions of each variable in detail. The sample comprises 4,002 REIT-year observations with valid ME and monthly returns over the period from 1990 to 2016. 


\section{Methodology}

In this study we sort all equity REITs with valid price and return information ${ }^{1}$ into quintiles based on their default risk (DD), and the portfolios are held from July for the subsequent 12 months. The portfolios are rebalanced every year and value-weighted portfolio returns are tracked over the whole sample period.

The long-short portfolio holds stocks in Quintile 1 (lowest default risk) and short sells stocks in Quintile 5 (highest default risk), representing a zero cost default risk investing strategy. Time-series variation of the longshort portfolio returns over the sample period is used to compute the significance level. The Newey and West (1987) procedure was applied to correct for serial correlation in returns.

An alternative measure of portfolio performance is to use risk-adjusted returns instead of raw returns. We use several asset pricing models to estimate risk-adjusted returns including the CAPM, the Fama and French (1993) three-factor model (FF3), the Fama and French (1993) and Carhart (1997) four-factor model (FFC), and the Fama and French (2015) five-factor model (FF5). The formulas of those asset pricing models are as follows:

$$
\begin{array}{lr}
r_{i, t}-r_{f, t}=\alpha_{i, \text { CAPM }}+\beta_{i, \text { Market }}\left(R_{m, t}-r_{f, t}\right)+\varepsilon_{i, t} & \text { CAPM } \\
r_{i, t}-r_{f, t}=\alpha_{i, F F 3}+\beta_{i, \text { Market }}\left(R_{m, t}-r_{f, t}\right)+ & \\
\beta_{i, S M B} S M B_{t}+\beta_{i, H M L} H M L_{t}+\varepsilon_{i, t} & \\
r_{i, t}-r_{f, t}=\alpha_{i, F F C}+\beta_{i, \text { Market }}\left(R_{m, t}-r_{f, t}\right)+ & \\
\beta_{i, S M B} S M B_{t}+\beta_{i, H M L} H M L_{t}+\beta_{i, U M D} U M D_{t}+\varepsilon_{i, t} & \text { FFC } \\
r_{i, t}-r_{f, t}=\alpha_{i, F F 5}+\beta_{i, M a r k e t}\left(R_{m, t}-r_{f, t}\right)+\beta_{i, S M B} S M B_{t}+ \\
\beta_{i, H M L} H M L_{t}+\beta_{i, R M W} R M W_{t}+\beta_{i, C M A} C M A_{t}+\varepsilon_{i, t} & \text { FF5 }
\end{array}
$$

where: $r_{i, t}$ is the portfolio return at time $t ; R_{m, t}$ is the market portfolio return at time $t ; r_{f, t}$ is the risk-free interest rate at time $t ; S M B_{t}, H M L_{t}, U M D_{t}, R M W_{t}$ and $C M A_{t}$ are size factor, value factor, momentum factor, profitability factor and investment factor at time $t$, respectively. Alphas estimated from the asset pricing models capture the riskadjusted returns.

The risk factors in the asset pricing models used in this study are calculated based on common stocks. Alternatively, we could generate risk factors based on REITs following Bond and Xue (2017), Chui et al. (2003), and Guidolin and Pedio (2019). We use common stock risk factors so that we can compare our results with the common stock literature and the REIT literature that also uses common stock risk factors (see, among others, Ooi et al., 2009; Cakici et al., 2014; Hao et al., 2016; Ling et al., 2019).

To investigate whether the long-short portfolio returns are associated with particular firm characteristics, we em-

\footnotetext{
1 There are 33 equity REITs delisted during the sample period and we use CRSP delisting returns where applicable.
}

ploy dependent double-sort analysis following Daniel and Titman (1997). The sorted portfolios are formed by sorting entities based on values of default risk and another particular variable in our study. In detail, we sort all equity REITs into two portfolios based on the value of the variable we aim to control for by using the median value. Within each portfolio, we sort stocks into three portfolios based on a 30/40/30 breakdown of default risk. This breakdown is used to ensure that we can investigate the default risk premium while controlling for certain firm characteristics, and ensure sufficient number of equity REITs in each portfolio. The double-sort will generate six portfolios in total. At the end of June in year $t$, we sort all the equity REITs into those six portfolios and these are held from July for the subsequent 12 months. The portfolios are rebalanced every year and value-weighted portfolio returns are tracked over the whole sample period. The objective of the double-sort analysis is to understand and investigate the relationship between stock returns and default risk conditional on the control variables such as asset growth or idiosyncratic volatility in our study.

\section{Empirical analysis}

\subsection{Default risk and returns}

Table 2 reports the returns of univariate sorted portfolios based on default risk measure DD. The average excess return from the low default risk portfolio is $0.999 \%$ per month $(t=4.13)$. The average excess return of the high default risk portfolio is $-0.248 \%$ per month $(t=-0.37)$, and is substantially lower than the other portfolios. In Panel B of Table 2, the default risk sorted portfolios has an increased factor loading on market risk. The negative relationship between default risk and equity REITs return is consistent with Campbell et al. (2008) and it documents that firms with higher default risk have generally underperformed.

Figure 1 plots the cumulative return of value-weighted portfolios with different levels of default risk and S\&P 500 index over the 1990-2016 period. Consistent with the portfolio performance in Table 2, default risk is negatively associated with equity REIT performance. The portfolio with lowest default risk (Q1) outperforms the S\&P 500 index after 2000 as well as higher default risk portfolios. The cumulative return of the portfolio with highest default risk (Q5) underperforms the S\&P 500 index over the sample period. The performance of investing in default risk, long REITs with low default risk and short REITs with high default risk, is strong over the period as a whole but it declines sharply over the period 2007-2009, which illustrates the strategy is sensitive to market (systematic) risk. The performance of the Q1 and long-short portfolios are similar over most of the sample period, suggesting that it is the long-side of the default risk strategy that is the main contributor to portfolio performance. Investing in the default risk strategy generates an annualized return of $17.8 \%$ over the sample period, which is much higher than 
Table 2. Returns on default risk sorted REIT portfolios

\begin{tabular}{|l|c|c|c|c|}
\hline & Low & 3 & High & Low-High \\
\hline \multicolumn{5}{|c|}{ Panel A: Portfolio alphas } \\
\hline Mean Excess & 0.999 & 0.945 & -0.248 & 1.246 \\
Return & $(4.13)$ & $(2.95)$ & $(-0.37)$ & $(2.26)$ \\
\hline CAPM Alpha & 0.633 & 0.469 & -0.988 & 1.621 \\
& $(2.84)$ & $(1.72)$ & $(-1.67)$ & $(3.14)$ \\
\hline FF-3 Alpha & 0.426 & 0.206 & -1.484 & 1.910 \\
& $(2.10)$ & $(0.78)$ & $(-2.77)$ & $(3.96)$ \\
\hline FF-4 Alpha & 0.459 & 0.379 & -1.084 & 1.542 \\
& $(2.19)$ & $(1.34)$ & $(-1.94)$ & $(3.09)$ \\
\hline FF-5 Alpha & 0.319 & 0.132 & -1.429 & 1.748 \\
& $(1.60)$ & $(0.51)$ & $(-2.75)$ & $(3.49)$ \\
\hline \multicolumn{5}{|c|}{ Panel B: Three-factor regression coefficients } \\
\hline RM & 0.590 & 0.762 & 1.177 & -0.587 \\
& $(7.76)$ & $(6.84)$ & $(5.81)$ & $(-3.89)$ \\
\hline SMB & 0.265 & 0.372 & 0.757 & -0.492 \\
& $(3.33)$ & $(3.40)$ & $(4.21)$ & $(-2.95)$ \\
\hline HML & 0.531 & 0.669 & 1.258 & -0.727 \\
& $(4.05)$ & $(3.84)$ & $(5.13)$ & $(-3.72)$ \\
\hline
\end{tabular}

Note: The table reports the monthly excess returns and abnormal returns for portfolios sorted on default risk. Default risk is measured by the distance of the expected value of firm's asset to the default point. High DD implies low likelihood of default. DD is constructed following Bharath and Shumway (2008). We form value-weighted quintile portfolios at the end of June each year and hold them for the subsequent 12 months. Panel A reports the value-weighted average monthly excess returns (in \%) on portfolios. The monthly average abnormal returns on portfolios are computed relative to the capital asset pricing model (CAPM) of Sharpe (1964) and Lintner (1965), the Fama and French (1993) three-factor (FF3) model, the Fama and French (1993) and Carhart (1997) four-factor (FFC) model, and the Fama and French (2015) five-factor (FF-5) model. Panel B reports the factor loadings of the FF-3 model. The period is from January 1990 to December 2016. the annualized return of the market index (11.0\%) over the same period.

The default risk investment strategy for REITs delivers returns of $1.246 \%$ per month and is significant at $5 \%$ level ( $\mathrm{t}$-statistics $=2.26$ ), as indicated by the long-short portfolio. The significant return is consistent across CAPM (1.621\% per month, t-statistics $=3.14)$, FF3 $(1.910 \%$ per month, t-statistics $=3.96)$, FFC $(1.542 \%$ per month, t-statistics $=3.09)$, and FF5 $(1.75 \%$, $t$-statistics $=1.75)$ riskadjusted returns. These results highlight that this default risk premium cannot be explained by taking common risk factors that are embedded in these models. Additionally, the long-short portfolio's negative factor loadings on MKT, SMB and HML imply that investors are able to exploit the default risk as a factor and can hedge unwanted risk exposures to market risk, or size and value.

We confirm the presence of a default risk premium across various robustness tests which are shown in Appendix C. To test the robustness of the weighting method of portfolio construction, we report the results of equallyweighted portfolio returns. To address the robustness of the sample, we report the results using the sample of all equity REITs, a sample dropping equity REITs with a price less than 1 dollar and a sample that follows Feng et al's (2011) definition of equity REITs. To address potential concerns about portfolio rebalancing frequency and date, we report results that rebalance the portfolios at the end of each month and rebalance the portfolios at the end of each January. To test whether the results are dependent upon the choice of default risk measure we report the results using Campbell et al's (2008) failure probability as the proxy for default risk. All the results in the robustness check do not materially deviate from the findings in Table 2, which suggest the default risk puzzle is persistent and not due to potential biases from research design.



Figure 1. Cumulative returns of the default risk sorted portfolios 


\subsection{Size, book-to-market ratio and the default risk premium}

Consistent with the existing literature (Dichev, 1998; Vassalou \& Xing, 2004; Campbell et al., 2008; Chava \& Purnanandam, 2010), we find that a default risk premium exists in equity REITs. This anomaly may be a result of the distinctive properties of REITs and we therefore investigate if the default risk premium can be explained by some fundamental characteristics.

Equity fundamental characteristics like market value of equity (ME) and book-to-market ratio (BM) are related to a number of anomalies in equity returns. To investigate whether the default risk premium is driven by the covariance between default risk and other factors, Table 3 presents double-sorted portfolio returns based on market value of equity (ME) and distance-to-default (DD). The premium of a low-minus-high default risk portfolio is still large and significant, $0.810 \%$ (t-statistics $=1.71$ ) per month in low ME group, and $0.479 \%$ per month (t-statistics $=1.68)$ in high ME group. The result shows that the negative relationship between default risk and equity return remains observable in both low and high ME groups. The negative pattern, therefore, results in a profitable default risk investment strategy even after controlling for size effects.

The premium in each size group is even higher in economic and statistical terms when the analysis is adjusted using various asset pricing models. The average monthly FF3 alpha, for example, is $1.350 \%$ and $0.836 \%$ in low and high ME group respectively (both with t-statistics over 3.0). The increase in risk-adjusted returns is similar to the findings in univariate sort analysis, attributable to negative factor loadings on MKT, SMB as well as HML (Untabulated for brevity). This provides further evidence that controlling for size does not explain the negative default risk-equity return puzzle nor the default risk premium.

We particularly pay attention to the difference in default risk premia between low and high ME groups. If the premium is associated with ME, we would expect the premium to be different across low and high ME groups. The differences in default risk premiums between the two ME groups are statistically insignificant, indicating that there is no statistically significant difference in default risk premium between low and high ME groups.

In Table 4, we report double-sorted portfolio returns based on book-to-market ratios (BM) and distance-todefault (DD). Premium of default risk strategy is positive in both BM groups but statistically insignificant, yielding at $0.304 \%$ per month in low BM group and $0.694 \%$ per month in high BM group. When CAPM, FF3, FFC and FF5 models are applied, the premium becomes statistically significant in the low BM group and increases by about $0.1-0.25 \%$, while the premiums in the high BM group are still insignificant except in the FF5 model. The differences in default risk premiums between two BM groups are statistically insignificant, indicating that there is no statistically significant difference in default risk premium between low and high BM groups.
Table 3. Default risk premium and size

\begin{tabular}{|c|c|c|c|c|}
\hline & $\begin{array}{c}\text { Low } \\
\text { Default } \\
\text { Risk }\end{array}$ & $\begin{array}{c}\text { Mid } \\
\text { Default } \\
\text { Risk }\end{array}$ & $\begin{array}{l}\text { High } \\
\text { Default } \\
\text { Risk }\end{array}$ & $\begin{array}{c}\text { Low-High } \\
\text { Default }\end{array}$ \\
\hline \multicolumn{5}{|c|}{ Excess return } \\
\hline Low ME & $\begin{array}{l}1.164 \\
(5.08)\end{array}$ & $\begin{array}{l}1.060 \\
(2.57)\end{array}$ & $\begin{array}{l}0.354 \\
(0.61)\end{array}$ & $\begin{array}{l}0.810 \\
(1.71)\end{array}$ \\
\hline High ME & $\begin{array}{l}0.976 \\
(3.83)\end{array}$ & $\begin{array}{l}0.892 \\
(2.92)\end{array}$ & $\begin{array}{l}0.497 \\
(1.11)\end{array}$ & $\begin{array}{l}0.479 \\
(1.68)\end{array}$ \\
\hline Low-High ME & & & & $\begin{array}{l}0.331 \\
(0.82)\end{array}$ \\
\hline \multicolumn{5}{|c|}{ CAPM alpha } \\
\hline Low ME & $\begin{array}{l}0.843 \\
(3.92)\end{array}$ & $\begin{array}{l}0.566 \\
(1.62)\end{array}$ & $\begin{array}{l}-0.292 \\
(-0.60)\end{array}$ & $\begin{array}{l}1.134 \\
(2.65)\end{array}$ \\
\hline High ME & $\begin{array}{l}0.586 \\
(2.47)\end{array}$ & $\begin{array}{l}0.419 \\
(1.53)\end{array}$ & $\begin{array}{l}-0.092 \\
(-0.24)\end{array}$ & $\begin{array}{l}0.678 \\
(2.68)\end{array}$ \\
\hline Low-High ME & & & & $\begin{array}{l}0.456 \\
(1.10) \\
\end{array}$ \\
\hline \multicolumn{5}{|c|}{ FF-3 alpha } \\
\hline Low ME & $\begin{array}{l}0.626 \\
(3.43) \\
\end{array}$ & $\begin{array}{l}0.202 \\
(0.64) \\
\end{array}$ & $\begin{array}{l}-0.724 \\
(-1.83)\end{array}$ & $\begin{array}{l}1.350 \\
(3.50)\end{array}$ \\
\hline High ME & $\begin{array}{l}0.364 \\
(1.67)\end{array}$ & $\begin{array}{l}0.144 \\
(0.55)\end{array}$ & $\begin{array}{l}-0.472 \\
(-1.44)\end{array}$ & $\begin{array}{l}0.836 \\
(3.57)\end{array}$ \\
\hline Low-High ME & & & & $\begin{array}{l}0.514 \\
(1.24) \\
\end{array}$ \\
\hline \multicolumn{5}{|c|}{ FFC alpha } \\
\hline Low ME & $\begin{array}{l}0.655 \\
(3.52) \\
\end{array}$ & $\begin{array}{l}0.434 \\
(1.32) \\
\end{array}$ & $\begin{array}{l}-0.374 \\
(-0.92) \\
\end{array}$ & $\begin{array}{l}1.029 \\
(2.55) \\
\end{array}$ \\
\hline High ME & $\begin{array}{l}0.412 \\
(1.85) \\
\end{array}$ & $\begin{array}{l}0.249 \\
(0.96) \\
\end{array}$ & $\begin{array}{l}-0.163 \\
(-0.46) \\
\end{array}$ & $\begin{array}{l}0.575 \\
(2.29) \\
\end{array}$ \\
\hline Low-High ME & & & & $\begin{array}{l}0.454 \\
(1.09)\end{array}$ \\
\hline \multicolumn{5}{|c|}{ FF-5 alpha } \\
\hline Low ME & $\begin{array}{l}0.543 \\
(2.86)\end{array}$ & $\begin{array}{l}0.259 \\
(0.87)\end{array}$ & $\begin{array}{l}-0.617 \\
(-1.42)\end{array}$ & $\begin{array}{l}1.160 \\
(2.69)\end{array}$ \\
\hline High ME & $\begin{array}{l}0.256 \\
(1.16) \\
\end{array}$ & $\begin{array}{l}0.029 \\
(0.12) \\
\end{array}$ & $\begin{array}{l}-0.450 \\
(-1.42) \\
\end{array}$ & $\begin{array}{l}0.706 \\
(2.82) \\
\end{array}$ \\
\hline Low-High ME & & & & $\begin{array}{l}0.453 \\
(1.01)\end{array}$ \\
\hline
\end{tabular}

Note: The table reports the monthly excess returns and abnormal returns for portfolios sorted on default risk and market value of equity. Default risk is measured by the distance of the expected value of firm's asset to the default point. High DD implies low likelihood of default. DD is constructed following Bharath and Shumway (2008). The market value of equity is the product of equity REIT's price and common shares outstanding (in million US dollars) at the end of June in year $t$. At the end June of year $t$, we first split all equity REITs by the median value of market value of equity, and then sort all REITs by using the 30/40/30 breakdown of DD in each group. We form the value-weighted portfolios at the end of June each year and hold them for the subsequent 12 months. The top panel reports the value-weighted average monthly excess returns (in \%) on portfolios. The monthly average abnormal returns on portfolios are computed relative to the capital asset pricing model (CAPM) of Sharpe (1964) and Lintner (1965), the Fama and French (1993) three-factor (FF-3) model, the Fama and French (1993) and Carhart (1997) fourfactor (FFC) model, and the Fama and French (2015) five-factor (FF-5) model. The period is from January 1990 to December 2016. 
Table 4. Default risk premium and book-to-market ratio

\begin{tabular}{|c|c|c|c|c|}
\hline & $\begin{array}{c}\text { Low } \\
\text { Default } \\
\text { Risk }\end{array}$ & $\begin{array}{c}\text { Mid } \\
\text { Default } \\
\text { Risk }\end{array}$ & $\begin{array}{l}\text { High } \\
\text { Default } \\
\text { Risk }\end{array}$ & $\begin{array}{l}\text { Low-High } \\
\text { Default }\end{array}$ \\
\hline \multicolumn{5}{|c|}{ Excess return } \\
\hline Low BM & $\begin{array}{l}1.076 \\
(4.41)\end{array}$ & $\begin{array}{l}1.101 \\
(3.83)\end{array}$ & $\begin{array}{l}0.773 \\
(2.18)\end{array}$ & $\begin{array}{l}0.304 \\
(1.25)\end{array}$ \\
\hline High BM & $\begin{array}{l}0.495 \\
(1.07)\end{array}$ & $\begin{array}{l}0.348 \\
(0.64)\end{array}$ & $\begin{array}{l}-0.199 \\
(-0.30)\end{array}$ & $\begin{array}{l}0.694 \\
(1.20)\end{array}$ \\
\hline Low-High BM & & & & $\begin{array}{l}-0.390 \\
(-0.69)\end{array}$ \\
\hline \multicolumn{5}{|c|}{ CAPM alpha } \\
\hline Low BM & $\begin{array}{l}0.718 \\
(3.16)\end{array}$ & $\begin{array}{l}0.673 \\
(2.56)\end{array}$ & $\begin{array}{l}0.283 \\
(0.93)\end{array}$ & $\begin{array}{l}0.435 \\
(1.85)\end{array}$ \\
\hline High BM & $\begin{array}{l}-0.093 \\
(-0.22)\end{array}$ & $\begin{array}{l}-0.297 \\
(-0.63)\end{array}$ & $\begin{array}{l}-0.899 \\
(-1.56)\end{array}$ & $\begin{array}{l}0.806 \\
(1.46)\end{array}$ \\
\hline Low-High BM & & & & $\begin{array}{l}-0.371 \\
(-0.66)\end{array}$ \\
\hline \multicolumn{5}{|c|}{ FF-3 alpha } \\
\hline Low BM & $\begin{array}{l}0.523 \\
(0.10)\end{array}$ & $\begin{array}{l}0.416 \\
(1.69) \\
\end{array}$ & $\begin{array}{l}0.026 \\
(2.46) \\
\end{array}$ & $\begin{array}{l}0.496 \\
(2.16) \\
\end{array}$ \\
\hline High BM & -0.481 & -0.695 & -1.316 & $\begin{array}{l}0.835 \\
(1.54)\end{array}$ \\
\hline Low-High BM & & & & $\begin{array}{c}-0.339 \\
-0.61\end{array}$ \\
\hline \multicolumn{5}{|c|}{ FFC alpha } \\
\hline Low BM & $\begin{array}{l}0.537 \\
(2.48) \\
\end{array}$ & $\begin{array}{l}0.474 \\
(1.88) \\
\end{array}$ & $\begin{array}{l}0.143 \\
(0.52) \\
\end{array}$ & $\begin{array}{l}0.394 \\
(1.73) \\
\end{array}$ \\
\hline High BM & $\begin{array}{l}-0.180 \\
(-0.43)\end{array}$ & $\begin{array}{l}-0.340 \\
(-0.70)\end{array}$ & $\begin{array}{l}-0.670 \\
(-1.27)\end{array}$ & $\begin{array}{l}0.490 \\
(0.83)\end{array}$ \\
\hline Low-High BM & 0.717 & 0.814 & 0.813 & $\begin{array}{l}-0.096 \\
(-0.16) \\
\end{array}$ \\
\hline \multicolumn{5}{|c|}{ FF-5 alpha } \\
\hline Low BM & $\begin{array}{l}0.399 \\
(1.92) \\
\end{array}$ & $\begin{array}{l}0.293 \\
(1.25) \\
\end{array}$ & $\begin{array}{l}-0.157 \\
(-0.54)\end{array}$ & $\begin{array}{l}0.556 \\
(2.69)\end{array}$ \\
\hline High BM & $\begin{array}{r}-0.504 \\
(-1.16) \\
\end{array}$ & $\begin{array}{l}-0.538 \\
(-1.36) \\
\end{array}$ & $\begin{array}{r}-1.092 \\
(-1.87) \\
\end{array}$ & $\begin{array}{l}0.588 \\
(2.82) \\
\end{array}$ \\
\hline Low-High BM & & & & $\begin{array}{l}-0.032 \\
(-0.05)\end{array}$ \\
\hline
\end{tabular}

Note: The table reports the monthly excess returns and abnormal returns for portfolios sorted on default risk and book-to-market equity ratio. Default risk is measured by the distance of the expected value of firm's asset to the default point. High DD implies low likelihood of default. DD is constructed following Bharath and Shumway (2008). The book-to-market equity ratio is calculated strictly following Davis et al. (2000) that is the fiscal year-end book value of equity in the $t-1$ year divided by the market value of equity at the end of December in $t-1$ year. Depending on the availability, book value of equity is defined as shareholder's equity (measured in the order depending on the availability: Compustat SEQ, Compustat CEQ + PSTK, or Compustat AT-LT) plus balance sheet deferred taxes and investment tax credit (Compustat TXDITC, if available), minus the book value of preferred stock (measured in the order depending on the availability: Compustat PSTKRV, Compustat PSTKL or Compustat PSTK). At the end June of year $t$, we first split all equity REITs by the median value of book-to-market equity ratio, and then sort all REITs by using the 30/40/30 breakdown of DD in each group. We form the value-weighted portfolios at the end of June each year and hold them for the subsequent 12 months. The top panel reports the value-weighted average monthly excess returns (in \%) on portfolios. The monthly average abnormal returns on portfolios are computed relative to the capital asset pricing model (CAPM) of Sharpe (1964) and Lintner (1965), the Fama and French (1993) three-factor (FF-3) model, the Fama and French (1993) and Carhart (1997) four-factor (FFC) model, and the Fama and French (2015) five-factor (FF-5) model. The period is from January 1990 to December 2016.

\subsection{The default risk premium and REIT-related pricing effect}

To investigate further the negative relationship between default risk and equity returns, in this section we test if the default risk premium is due to the variation of asset growth (AG) and idiosyncratic volatility (IVOL). In equity REITs, both AG and IVOL are significant anomalies which are unexplained by asset pricing models, we test if the default risk premium is related to them using dependent double-sort portfolio analysis.

\subsubsection{Default risk and asset growth}

Hou et al. (2015) document that a pricing factor based on asset growth (Cooper et al., 2008) can explain the significance of default risk premium. They argue that asset growth represents a risk and aggressive investments alter investor expectations on equity returns. Ling et al. (2019) find that REIT asset growth is driven primarily by expansions in their real estate holdings and $58.3 \%$ of the financing is funded by additional debt. Raising debt to fund investment projects may put pressure on a REIT's cash flow and therefore increase the risk of default, which potentially is reflected in the default risk premium.

We test if the default risk premium is more prominent in REITs with high asset growth than low asset growth REITs. Table 5 reports the double-sorted portfolio returns based on asset growth (AG) and distance-to-default (DD). The return on low-minus-high default risk portfolio is $0.607 \%$ with t-statistic of 1.18 for REITs with low asset growth and $0.118 \%$ with t-statistic of 0.36 for REITs with high asset growth. This is not consistent with the conceptual justification that the default risk premium is more pronounced in high asset growth stocks. Additionally, the abnormal returns in the low asset growth group of CAPM and FF3 models are positive and statistically significant with $0.787 \%$ and $1.83 \%$, respectively. Other abnormal returns produced by all asset pricing models are insignificant.

Since the double-sorted portfolio analysis controls the effect of AG, a statistically significant difference in default risk premium between low AG and high AG groups would support the asset growth explanation. We do not find robust evidence that default risk premium can be explained by asset growth. The difference is $0.489 \%$ per month without risk-adjustment, or between $0.376 \%$ and $0.663 \%$ with riskadjustments. None of the five differences are statistically significant. The combined reading of the default risk premium and their difference does not give compelling support to the effect of asset growth on the default risk premium. 
Table 5. Default risk premium and asset growth

\begin{tabular}{|c|c|c|c|c|}
\hline & $\begin{array}{c}\text { Low } \\
\text { Default } \\
\text { Risk }\end{array}$ & $\begin{array}{c}\text { Mid } \\
\text { Default } \\
\text { Risk }\end{array}$ & $\begin{array}{c}\text { High } \\
\text { Default } \\
\text { Risk }\end{array}$ & $\begin{array}{l}\text { Low-High } \\
\text { Default }\end{array}$ \\
\hline \multicolumn{5}{|c|}{ Excess return } \\
\hline Low $A G$ & $\begin{array}{l}0.690 \\
(2.08)\end{array}$ & $\begin{array}{l}0.630 \\
(1.51)\end{array}$ & $\begin{array}{l}0.082 \\
(0.13)\end{array}$ & $\begin{array}{l}0.607 \\
(1.18)\end{array}$ \\
\hline High AG & $\begin{array}{l}0.916 \\
(3.61)\end{array}$ & $\begin{array}{l}0.969 \\
(3.21)\end{array}$ & $\begin{array}{l}0.798 \\
(1.70)\end{array}$ & $\begin{array}{l}0.118 \\
(0.36)\end{array}$ \\
\hline Low-High AG & & & & $\begin{array}{l}0.489 \\
(0.99)\end{array}$ \\
\hline \multicolumn{5}{|c|}{ CAPM alpha } \\
\hline Low $A G$ & $\begin{array}{l}0.231 \\
(0.74)\end{array}$ & $\begin{array}{l}0.086 \\
(0.24)\end{array}$ & $\begin{array}{l}-0.647 \\
(-1.21)\end{array}$ & $\begin{array}{l}0.878 \\
(1.83)\end{array}$ \\
\hline High AG & $\begin{array}{l}0.556 \\
(2.37)\end{array}$ & $\begin{array}{l}0.527 \\
(1.99)\end{array}$ & $\begin{array}{l}0.306 \\
(0.73)\end{array}$ & $\begin{array}{l}0.250 \\
(0.79)\end{array}$ \\
\hline Low-High AG & & & & $\begin{array}{l}0.628 \\
(1.30)\end{array}$ \\
\hline \multicolumn{5}{|c|}{ FF-3 alpha } \\
\hline Low AG & $\begin{array}{l}-0.011 \\
(-0.04)\end{array}$ & $\begin{array}{l}-0.279 \\
(-0.84)\end{array}$ & $\begin{array}{l}-1.072 \\
(-2.30)\end{array}$ & $\begin{array}{l}1.061 \\
(2.35)\end{array}$ \\
\hline High AG & $\begin{array}{l}0.329 \\
(1.57)\end{array}$ & $\begin{array}{l}0.299 \\
(1.17)\end{array}$ & $\begin{array}{l}-0.070 \\
(-0.19)\end{array}$ & $\begin{array}{l}0.398 \\
(1.34)\end{array}$ \\
\hline Low-High AG & & & & $\begin{array}{l}0.663 \\
(1.34)\end{array}$ \\
\hline \multicolumn{5}{|c|}{ FFC alpha } \\
\hline Low AG & $\begin{array}{l}0.141 \\
(0.49) \\
\end{array}$ & $\begin{array}{l}0.003 \\
(0.01) \\
\end{array}$ & $\begin{array}{l}-0.480 \\
(-1.00) \\
\end{array}$ & $\begin{array}{l}0.622 \\
(1.31) \\
\end{array}$ \\
\hline High AG & $\begin{array}{l}0.380 \\
(1.78) \\
\end{array}$ & $\begin{array}{l}0.342 \\
(1.31) \\
\end{array}$ & $\begin{array}{l}0.135 \\
(0.35) \\
\end{array}$ & $\begin{array}{l}0.245 \\
(0.76)\end{array}$ \\
\hline Low-High AG & & & & $\begin{array}{l}0.377 \\
(0.75)\end{array}$ \\
\hline \multicolumn{5}{|c|}{ FF-5 alpha } \\
\hline Low $A G$ & $\begin{array}{l}-0.153 \\
(-0.49)\end{array}$ & $\begin{array}{l}-0.348 \\
(-1.10)\end{array}$ & $\begin{array}{l}-0.877 \\
(-1.68)\end{array}$ & $\begin{array}{l}0.724 \\
(1.37)\end{array}$ \\
\hline High AG & $\begin{array}{l}0.239 \\
(1.16) \\
\end{array}$ & $\begin{array}{l}0.240 \\
(1.01) \\
\end{array}$ & $\begin{array}{l}-0.109 \\
(-0.30) \\
\end{array}$ & $\begin{array}{l}0.348 \\
(1.12) \\
\end{array}$ \\
\hline Low-High AG & & & & $\begin{array}{l}0.376 \\
(0.72)\end{array}$ \\
\hline
\end{tabular}

Note: The table reports the monthly excess returns and abnormal returns for portfolios sorted on default risk and asset growth. Default risk is measured by the distance of the expected value of firm's asset to the default point. High DD implies low likelihood of default. DD is constructed following Bharath and Shumway (2008). Asset growth is defined as the difference of Firm's total asset (Compustat AT) in fiscal year $t-1$ and $t-2$, scaled by the $t-2$ total assets. At the end June of year $t$, we first split all equity REITs by the median value of asset growth, and then sort all REITs by using the 30/40/30 breakdown of DD in each group. We form the value-weighted portfolios at the end of June each year and hold them for the subsequent 12 months. The top panel reports the value-weighted average monthly excess returns (in \%) on portfolios. The monthly average abnormal returns on portfolios are computed relative to the capital asset pricing model (CAPM) of Sharpe (1964) and Lintner (1965), the Fama and French (1993) three-factor (FF-3) model, the Fama and French (1993) and Carhart (1997) four-factor (FFC) model, and the Fama and French (2015) five-factor (FF-5) model. The period is from January 1990 to December 2016.

\subsubsection{Default risk and idiosyncratic volatility}

Stambaugh et al. (2015) find evidence that default risk premium is more pronounced among stocks with high idiosyncratic volatility (IVOL). They argue that high idiosyncratic volatility implies additional risk for the arbitrageur and that these stocks are hard to short sell. In REITs, idiosyncratic volatility has received extensive research, and Cakici et al. (2014) find the pricing effect of IVOL in REITs is stronger than in ordinary shares. We therefore investigate the relationship between default risk and idiosyncratic volatility.

Table 6 reports the distress risk premium after controlling for the effect of idiosyncratic volatility (IVOL). The default risk premium is $0.426 \%$ per month with $t$-statistics of 1.59 for low IVOL group and $0.921 \%$ per month with tstatistics of 1.64 for high IVOL group, suggesting that the default risk premium might be positively associated with idiosyncratic volatility. This relationship is also shown after adjusting performance using CAPM $(0.426 \%$ against $0.921 \%)$, FF3 (0.642\% against $1.266 \%)$, FFC $(0.411 \%$ against $0.929 \%)$, as well as FF5 (0.629\% against $1.230 \%)$. The premiums are statistically significant in both low and high IVOL groups when CAPM, FF3 and FF5 models are applied.

Although the default risk premium is more prominent in high IVOL REITs, the differences of the premium between high and low idiosyncratic volatility groups are not statistically significant, indicating that there is no statistically significant difference in default risk premium between low and high IVOL groups. This is inconsistent with Stambaugh et al. (2015), who argue the distress puzzle only exists in high IVOL stocks where arbitraging activities are difficult and risky.

Table 6. Default risk premium and idiosyncratic volatility

\begin{tabular}{|c|c|c|c|c|}
\hline & $\begin{array}{c}\text { Low } \\
\text { Default } \\
\text { Risk }\end{array}$ & $\begin{array}{c}\text { Mid } \\
\text { Default } \\
\text { Risk }\end{array}$ & $\begin{array}{c}\text { High } \\
\text { Default } \\
\text { Risk }\end{array}$ & $\begin{array}{c}\text { Low-High } \\
\text { Default }\end{array}$ \\
\hline \multicolumn{5}{|c|}{ Excess return } \\
\hline Low IVOL & $\begin{array}{l}1.015 \\
(4.03)\end{array}$ & $\begin{array}{l}0.920 \\
(2.82)\end{array}$ & $\begin{array}{l}0.589 \\
(1.51)\end{array}$ & $\begin{array}{l}0.426 \\
(1.59)\end{array}$ \\
\hline High IVOL & $\begin{array}{l}0.984 \\
(3.05)\end{array}$ & $\begin{array}{l}1.088 \\
(2.13)\end{array}$ & $\begin{array}{l}0.064 \\
(0.10)\end{array}$ & $\begin{array}{l}0.921 \\
(1.64)\end{array}$ \\
\hline $\begin{array}{l}\text { Low-High } \\
\text { IVOL }\end{array}$ & 0.030 & -0.168 & 0.525 & $\begin{array}{l}-0.495 \\
(-1.00) \\
\end{array}$ \\
\hline \multicolumn{5}{|c|}{ CAPM alpha } \\
\hline Low IVOL & $\begin{array}{l}0.657 \\
(2.82)\end{array}$ & $\begin{array}{l}0.467 \\
(1.57)\end{array}$ & $\begin{array}{l}0.122 \\
(0.35)\end{array}$ & $\begin{array}{l}0.535 \\
(2.01)\end{array}$ \\
\hline High IVOL & $\begin{array}{l}0.552 \\
(1.92)\end{array}$ & $\begin{array}{l}0.480 \\
(1.15)\end{array}$ & $\begin{array}{l}-0.613 \\
(-1.04)\end{array}$ & $\begin{array}{l}1.165 \\
(2.13)\end{array}$ \\
\hline $\begin{array}{l}\text { Low-High } \\
\text { IVOL }\end{array}$ & 0.105 & -0.012 & 0.735 & $\begin{array}{l}-0.630 \\
(-1.26)\end{array}$ \\
\hline
\end{tabular}


End of Table 6

\begin{tabular}{|l|c|c|c|c|}
\hline & $\begin{array}{c}\text { Low } \\
\text { Default } \\
\text { Risk }\end{array}$ & $\begin{array}{c}\text { Mid } \\
\text { Default } \\
\text { Risk }\end{array}$ & $\begin{array}{c}\text { High } \\
\text { Default } \\
\text { Risk }\end{array}$ & $\begin{array}{c}\text { Low-High } \\
\text { Default }\end{array}$ \\
\hline \multicolumn{5}{|c|}{ FF-3 alpha } \\
\hline Low IVOL & 0.463 & 0.201 & -0.179 & 0.642 \\
& $(2.18)$ & $(0.70)$ & $(-0.57)$ & $(2.47)$ \\
\hline High IVOL & 0.259 & 0.080 & -1.007 & 1.266 \\
\hline Low-High & $(1.03)$ & $(0.22)$ & $(-2.00)$ & $(2.41)$ \\
\hline IVOL & 0.204 & 0.121 & 0.827 & -0.624 \\
& \multicolumn{5}{|c|}{ FFC alpha } & $(-1.23)$ \\
\hline Low IVOL & 0.495 & 0.290 & 0.084 & 0.411 \\
& $(2.28)$ & $(1.02)$ & $(0.27)$ & $(1.62)$ \\
\hline High IVOL & 0.391 & 0.418 & -0.539 & 0.929 \\
& $(1.54)$ & $(1.06)$ & $(-1.03)$ & $(1.76)$ \\
\hline Low-High & 0.105 & -0.128 & 0.623 & -0.518 \\
IVOL & $(1.02)$ & $(0.42)$ & $(-1.72)$ & $(2.04)$ \\
\hline Low-High & 0.138 & -0.024 & 0.740 & -0.602 \\
\hline High IVOL & 0.244 & 0.145 & -0.986 & 1.230 \\
\hline & 0.383 & 0.121 & -0.246 & 0.629 \\
& $(1.82)$ & $(0.43)$ & $(-0.81)$ & $(2.35)$ \\
\hline & & & & $(-1.06)$ \\
\hline
\end{tabular}

Note: The table reports the monthly excess returns and abnormal returns for portfolios sorted on default risk and idiosyncratic volatility. Default risk is measured by the distance of the expected value of firm's asset to the default point. High DD implies low likelihood of default. DD is constructed following Bharath and Shumway (2008). Idiosyncratic volatility is measured as Ang et al. (2006) (see Appendix B for details). At the end June of year $t$, we first split all equity REITs by the median value of idiosyncratic volatility, and then sort all REITs by using the 30/40/30 breakdown of DD in each group. We form the value-weighted portfolios at the end of each month and hold them for the following month. The top panel reports the value-weighted average monthly excess returns (in $\%)$ on portfolios. The monthly average abnormal returns on portfolios are computed relative to the capital asset pricing model (CAPM) of Sharpe (1964) and Lintner (1965), the Fama and French (1993) three-factor (FF-3) model, the Fama and French (1993) and Carhart (1997) fourfactor (FFC) model, and the Fama and French (2015) five-factor (FF-5) model. The period is from January 1990 to December 2016.

\section{Further discussion}

\subsection{Is default risk investment strategy equivalent to quality asset investment strategy?}

The quality factor theory argues that assets with characteristics such as high profitability, payout ratio, growth rate and safety are associated with high expected return. Anzinger et al. (2017) construct a quality factor for REITs by using the estimates of profitability, growth rate, safety and payout ratio. They found that quality factor investing (long good quality REITs and short bad quality REITs) generates a return of $12.93 \%$ per annum in the 1999-2013 period. Solely investing based on safety (long safe REITs and short risky REITs) generates an annual return of $7.96 \%$. Their safety measure is based on Altman (1968) Z-score default risk measure. Our results find that adopting a single measure of default risk, the default risk premium (14.95\% per annum) itself is larger than the whole quality premium. This suggests that default risk investment strategy is not equivalent to a quality asset investment strategy.

\subsection{Is default risk premium due to limit of arbitrage}

Campbell et al. (2008) argue the default risk premium seems too high to be rational. Limit of arbitrage theory claims market frictions such as bid-ask spreads, shortselling constraints make some investment opportunities impossible to achieve. Specifically, Novy-Marx and Velikov (2015) find the default risk premium is not statistically significant adjusting for risks and transaction costs, because the short-side of the default risk strategy (short-selling high default risk stocks) are small stocks and associated with high transaction costs. The difficulty in short-selling high default risk stocks is also observed by Stambaugh et al. (2015), supporting the view that the arbitrage limit effect is behind the distress puzzle and results in the profitability of such a hypothetical trading strategy.

However, as shown in Figure 1, the profitability of default risk strategy in REITs is mainly contributed by the long-side (buy and hold the low default risk REITs) which constantly beat all other REITs and the market performance. The factor loadings of SMB in Table 2 also confirm that low default risk REITs tend to be large stocks, which are unlikely to have high transaction costs. This evidence shows that REITs are different from common stocks, and the limit of arbitrage effect is not accounting for the default risk premium in REITs.

\subsection{Possible explanation of default risk premium}

We find striking evidence showing that the default risk premium is associated with general stock market risk. Table 7 reports the default risk premium controlling for the effect of market risk measured by CAPM beta. The default risk premium in low beta REITs is marginal and statistically insignificant $(0.154 \%$ with $\mathrm{t}$-statistic of 0.40$)$. Especially when results are adjusted by FFC model, the premium is only $0.02 \%$ (t-statistic $=0.06)$ in low beta REITs in sharp contrast with the $1.052 \%(\mathrm{t}$-statistic $=2.50)$ in high beta REITs.

The difference of default risk premium in low and high market risk group is significant in 4 out of 5 performance measurements, including CAPM alpha ( $t$-statistic $=-1.78)$, FF3 alpha (t-statistic $=-2.02)$, FFC alpha ( $\mathrm{t}$-statistic $=-2.01)$ as well as FF5 alpha $(\mathrm{t}=-1.78)$. The results show that the default risk premium is associated with market risk. For the low market risk REITs, default risk is irrelevant to their return. On the other hand, ignoring or 
underestimating default risk will result in mispricing of the return of REITs with high market risk. Thus, default risk premium exists amongst high market risk REITs.

Due to the relatively low likelihood of default, it is perhaps not surprising that investors may ignore or underestimate the default risk. Such behaviour would not cause any mispricing for REITs that have low market risk, but this will cause mispricing for REITs have relatively high market risk.

Table 7. Default risk premium and CAPM beta

\begin{tabular}{|c|c|c|c|c|}
\hline & $\begin{array}{c}\text { Low } \\
\text { Default } \\
\text { Risk }\end{array}$ & $\begin{array}{c}\text { Mid } \\
\text { Default } \\
\text { Risk }\end{array}$ & $\begin{array}{c}\text { High } \\
\text { Default } \\
\text { Risk }\end{array}$ & $\begin{array}{l}\text { Low-High } \\
\text { Default }\end{array}$ \\
\hline \multicolumn{5}{|c|}{ Excess return } \\
\hline Low Beta & $\begin{array}{l}1.052 \\
(3.89)\end{array}$ & $\begin{array}{l}1.029 \\
(3.56)\end{array}$ & $\begin{array}{l}0.898 \\
(1.92)\end{array}$ & $\begin{array}{l}0.154 \\
(0.40)\end{array}$ \\
\hline High Beta & $\begin{array}{l}0.927 \\
(3.10)\end{array}$ & $\begin{array}{l}0.838 \\
(1.96)\end{array}$ & $\begin{array}{l}0.021 \\
(0.03)\end{array}$ & $\begin{array}{l}0.905 \\
(1.91)\end{array}$ \\
\hline $\begin{array}{l}\text { Low-High } \\
\text { Beta }\end{array}$ & 0.125 & 0.191 & 0.876 & $\begin{array}{l}-0.751 \\
(-1.43)\end{array}$ \\
\hline \multicolumn{5}{|c|}{ CAPM alpha } \\
\hline Low Beta & $\begin{array}{l}0.678 \\
(2.62)\end{array}$ & $\begin{array}{l}0.644 \\
(2.37)\end{array}$ & $\begin{array}{l}0.492 \\
(1.16)\end{array}$ & $\begin{array}{l}0.186 \\
(0.48)\end{array}$ \\
\hline High Beta & $\begin{array}{l}0.458 \\
(1.76)\end{array}$ & $\begin{array}{l}0.267 \\
(0.74)\end{array}$ & $\begin{array}{l}-0.654 \\
(-1.20)\end{array}$ & $\begin{array}{l}1.113 \\
(2.49)\end{array}$ \\
\hline $\begin{array}{l}\text { Low-High } \\
\text { Beta }\end{array}$ & 0.219 & 0.377 & 1.146 & $\begin{array}{l}-0.927 \\
(-1.78)\end{array}$ \\
\hline \multicolumn{5}{|c|}{ FF-3 alpha } \\
\hline Low Beta & $\begin{array}{l}0.468 \\
(1.93)\end{array}$ & $\begin{array}{l}0.435 \\
(1.72)\end{array}$ & $\begin{array}{l}0.213 \\
(0.57)\end{array}$ & $\begin{array}{l}0.255 \\
(0.67)\end{array}$ \\
\hline High Beta & $\begin{array}{l}0.176 \\
(0.73)\end{array}$ & $\begin{array}{l}-0.079 \\
(-0.26)\end{array}$ & $\begin{array}{l}-1.119 \\
(-2.51)\end{array}$ & $\begin{array}{l}1.294 \\
(3.17)\end{array}$ \\
\hline $\begin{array}{l}\text { Low-High } \\
\text { Beta }\end{array}$ & 0.292 & 0.514 & 1.331 & $\begin{array}{l}-1.039 \\
(-2.02)\end{array}$ \\
\hline \multicolumn{5}{|c|}{ FFC alpha } \\
\hline Low Beta & $\begin{array}{l}0.527 \\
(2.14)\end{array}$ & $\begin{array}{l}0.515 \\
(2.00)\end{array}$ & $\begin{array}{l}0.507 \\
(1.45)\end{array}$ & $\begin{array}{l}0.020 \\
(0.06)\end{array}$ \\
\hline High Beta & $\begin{array}{l}0.275 \\
(1.09)\end{array}$ & $\begin{array}{l}0.133 \\
(0.39)\end{array}$ & $\begin{array}{c}-0.777 \\
(0.39)\end{array}$ & $\begin{array}{l}1.052 \\
(2.50)\end{array}$ \\
\hline $\begin{array}{l}\text { Low-High } \\
\text { Beta }\end{array}$ & 0.252 & 0.382 & 1.284 & $\begin{array}{l}-1.032 \\
(-2.01)\end{array}$ \\
\hline \multicolumn{5}{|c|}{ FF-5 alpha } \\
\hline Low Beta & $\begin{array}{l}0.346 \\
(1.47)\end{array}$ & $\begin{array}{l}0.339 \\
(1.35)\end{array}$ & $\begin{array}{l}0.153 \\
(0.40)\end{array}$ & $\begin{array}{l}0.194 \\
(2.35)\end{array}$ \\
\hline High Beta & $\begin{array}{l}0.118 \\
(0.49)\end{array}$ & $\begin{array}{l}-0.119 \\
(-0.40)\end{array}$ & $\begin{array}{l}-1.042 \\
(-2.22)\end{array}$ & $\begin{array}{l}1.160 \\
(2.04)\end{array}$ \\
\hline $\begin{array}{l}\text { Low-High } \\
\text { Beta }\end{array}$ & 0.228 & 0.458 & 1.195 & $\begin{array}{l}-0.967 \\
(-1.78)\end{array}$ \\
\hline
\end{tabular}

Note: The table reports the monthly excess returns and abnormal returns for portfolios sorted on default risk and the five-year CAPM beta. Default risk is measured by the distance of the expected value of firm's asset to the default point. High DD implies low likelihood of default. DD is constructed following Bharath and Shumway (2008). The fiveyear CAPM beta is estimated as Fama and French (1996). A REIT's monthly return in excess of one-month US treasury bill rate is regressed by the value-weighted excess return of CRSP index in the given month: $R_{i, t}-r_{f, t}=\alpha_{i, t}+\beta_{C A P M, t}\left(R_{m, t}-r_{f, t}\right)+\varepsilon_{i, t}$. The coefficient of market excess return is the monthly CAPM beta for the REIT. We take a rolling window at 60 months to obtain the averaged value of the five-year CAPM beta, and a minimum of 36 months with non-missing value for conducting regressions is required. If the valid monthly return is less than 36 months in the rolling window, the five-year CAPM beta is set as missing. At the end June of year $t$, we first split all equity REITs by the median value of the five-year CAPM beta, and then sort all REITs by using the 30/40/30 breakdown of DD in each group. We form the value-weighted portfolios at the end of each month and hold them for the following month. The top panel reports the value-weighted average monthly excess returns (in \%) on portfolios. The monthly average abnormal returns on portfolios are computed relative to the capital asset pricing model (CAPM) of Sharpe (1964) and Lintner (1965), the Fama and French (1993) three-factor (FF-3) model, the Fama and French (1993) and Carhart (1997) four-factor (FFC) model, and the Fama and French (2015) five-factor (FF-5) model. The period is from January 1990 to December 2016.

\subsection{Practical insights for investors}

Our paper documents that a default risk investment strategy (long low default risk REITs and short high default risk REITs) generates a return of $15 \%$ per annum. Additionally, risk-adjusting the portfolio returns using the CAPM, the Fama and French (1993) three-factor model, the Fama and French (1993) and Carhart (1997) four-factor model, and the Fama and French (2015) five-factor model shows that the default risk premium cannot be explained by the risk factors in the main asset pricing models. The strategy is forward-looking and hence shows that default risk has ability to predict cross-sectional variation in future stock returns in REITs over the period of study.

Bankruptcy, default and delisting rarely happen in REITs, but this does not mean that default risk can be ignored in REIT investment. The study shows a trading strategy based on the REIT's default risk generates a nontrivial return.

\section{Conclusions}

This paper contributes to the real estate literature by examining the relationship between default risk and return of REITs. Default risk is measured by DD which is an option pricing based model and is superior to other default risk measures such as $\mathrm{O}$-score and $\mathrm{Z}$-score (Hillegeist et al., 2004). Furthermore, accounting information based default risk models are heavily reliant on a firm's leverage, cash holding, dividends which are not appropriate for REITs. We found that default risk appears to be mispriced in the share prices of REITs. Default risk is negatively associated with the return of REITs, which is consistent with the common stock literature. A default risk investment strategy (long low default risk REITs and short high default risk REITs) generates a return of $15 \%$ per annum or a risk-adjusted return around $20 \%$ per annum. We find the default risk premia are not statistically different 
between low and high firm size, low and high book-tomarket ratio, low and high asset growth rate or low and high idiosyncratic volatility, showing that our findings are not simply a spurious relationship to these anomalies. However, the default risk premia are significantly different in REITs between low and high CAPM beta. The distress premium disappears in the low beta REITs group and exists in the high beta REITs group. Due to the relatively low likelihood of default, it seems likely that investors tend to ignore or underestimate default risk. Such behaviour would not cause any major mispricing for REITs that have low market risk, but this will cause mispricing for REITs that have relatively high market risk.

Our finding should be of interest to investors looking to generate alpha from investing in REITs. Default risk has provided an effective investment strategy among US equity REITs. Both raw and risk-adjusted average returns are higher than previous documented anomalies in REITs, such as asset growth, idiosyncratic volatility and quality factors.

\section{References}

Altman, E. I. (1968). Financial ratios, discriminant analysis and the prediction of corporate bankruptcy. The Journal of Finance, 23(4), 589-609. https://doi.org/10.2307/2978933

Ang, A., Hodrick, R. J., Xing, Y., \& Zhang, X. (2006). The crosssection of volatility and expected returns. The Journal of Finance, 61(1), 259-299.

https://doi.org/10.1111/j.1540-6261.2006.00836.x

Anzinger, S. K., Ghosh, C., \& Petrova, M. (2017). The other side of value: the effect of quality on price and return in real estate. The Journal of Real Estate Finance and Economics, 54(3), 429-457. https://doi.org/10.1007/s11146-016-9574-Z

Bharath, S. T., \& Shumway, T. (2008). Forecasting default with the Merton distance to default model. Review of Financial Studies, 21(3), 1339-1369. https://doi.org/10.1093/rfs/hhn044

Bond, S., \& Xue, C. (2017). The cross section of expected real estate returns: insights from investment-based asset pricing. The Journal of Real Estate Finance and Economics, 54(3), 403-428. https://doi.org/10.1007/s11146-016-9573-0

Cakici, N., Erol, I., \& Tirtiroglu, D. (2014). Tracking the evolution of idiosyncratic risk and cross-sectional expected returns for US REITs. The Journal of Real Estate Finance and Economics, 48(3), 415-440. https://doi.org/10.1007/s11146-013-9410-7

Campbell, J. Y., Hilscher, J., \& Szilagyi, J. (2008). In search of distress risk. The Journal of Finance, 63(6), 2899-2939. https://doi.org/10.1111/j.1540-6261.2008.01416.x

Carhart, M. M. (1997). On persistence in mutual fund performance. The Journal of Finance, 52(1), 57-82. https://doi.org/10.1111/j.1540-6261.1997.tb03808.x

Charitou, A., Dionysiou, D., Lambertides, N., \& Trigeorgis, L. (2013). Alternative bankruptcy prediction models using option-pricing theory. Journal of Banking \& Finance, 37(7), 2329-2341. https://doi.org/10.1016/j.jbankfin.2013.01.020

Chava, S., \& Purnanandam, A. (2010). Is default risk negatively related to stock returns? Review of Financial Studies, 23(6), 2523-2559. https://doi.org/10.1093/rfs/hhp107

Chui, A. C. W., Titman, S., \& Wei, K. C. J. (2003). The cross section of expected REIT returns. Real Estate Economics, 31(3), 451-479. https://doi.org/10.1111/1540-6229.00073
Chung, R., Fung, S., Shilling, J. D., \& Simmons-Mosley, T. X. (2016). REIT stock market volatility and expected returns. Real Estate Economics, 44(4), 968-995.

https://doi.org/10.1111/1540-6229.12128

Cooper, M. J., Gulen, H., \& Schill, M. J. (2008). Asset growth and the cross-section of stock returns. The Journal of Finance, 63(4), 1609-1651. https://doi.org/10.1111/j.1540-6261.2008.01370.x

Daniel, K., \& Titman, S. (1997). Evidence on the characteristics of cross sectional variation in stock returns. The Journal of Finance, 52(1), 1-33. https://doi.org/10.1111/j.1540-6261.1997.tb03806.x

Davis, J. L., Fama, E. F., \& French, K. R. (2000). Characteristics, covariances, and average returns: 1929 to 1997. The Journal of Finance, 55(1), 389-406. https://doi.org/10.1111/0022-1082.00209

DeLisle, J., Price, S. M., \& Sirmans, C. F. (2013). Pricing of volatility risk in REITs. Journal of Real Estate Research, 35(2), 223-248. https://aresjournals.org/doi/pdf/10.5555/ rees.35.2.92q1v49220220861

Dichev, I. D. (1998). Is the risk of bankruptcy a systematic risk? The Journal of Finance, 53(3), 1131-1147. https://doi.org/10.1111/0022-1082.00046

Fama, E. F., \& French, K. R. (1992). The cross-section of expected stock returns. The Journal of Finance, 47(2), 427-465. https://doi.org/10.2307/2329112

Fama, E. F., \& French, K. R. (1993). Common risk factors in the returns on stocks and bonds. Journal of Financial Economics, 33(1), 3-56. https://doi.org/10.1016/0304-405x(93)90023-5

Fama, E. F., \& French, K. R. (1996). Multifactor explanations of asset pricing anomalies. The Journal of Finance, 51(1), 55-84. https://doi.org/10.1111/j.1540-6261.1996.tb05202.x

Fama, E. F., \& French, K. R. (2015). A five-factor asset pricing model. Journal of Financial Economics, 116(1), 1-22. https://doi.org/10.1016/j.jfineco.2014.10.010

Fama, E. F., \& French, K. R. (2016). Dissecting anomalies with a five-factor model. Review of Financial Studies, 29(1), 69-103. https://doi.org/10.1093/rfs/hhv043

Feng, Z., Price, S. M., \& Sirmans, C. F. (2011). An overview of equity real estate investment trusts (REITs): 1993-2009. Journal of Real Estate Literature, 19(2), 307-343.

Giacomini, E., Ling, D. C., \& Naranjo, A. (2015). Leverage and returns: a cross-country analysis of public real estate markets. The Journal of Real Estate Finance and Economics, 51(2), 125-159. https://doi.org/10.1007/s11146-014-9489-5

Giacomini, E., Ling, D. C., \& Naranjo, A. (2017). REIT leverage and return performance: keep your eye on the target. Real Estate Economics, 45(4), 930-978.

https://doi.org/10.1111/1540-6229.12179

Guidolin, M., \& Pedio, M. (2019). How smart is the real estate smart beta? Evidence from optimal style factor strategies for REITs (BAFFI CAREFIN Centre Research Paper No. 2019117). https://doi.org/10.2139/ssrn.3458308

Hao, Y., Chu, H.-H., Ko, K.-C., \& Lin, L. (2016). Momentum strategies and investor sentiment in the REIT market. International Review of Finance, 16(1), 41-71. https://doi.org/10.1111/irfi.12060

Hillegeist, S. A., Keating, E. K., Cram, D. P., \& Lundstedt, K. G. (2004). Assessing the probability of bankruptcy. Review of Accounting Studies, 9(1), 5-34. https://doi.org/10.1023/b:rast.0000013627.90884.b7

Hou, K., Xue, C., \& Zhang, L. (2015). Digesting anomalies: an investment approach. Review of Financial Studies, 28(3), 650705. https://doi.org/10.1093/rfs/hhu068 
Kawaguchi, Y., Sa-Aadu, J., \& Shilling, J. D. (2017). REIT stock price volatility and the effects of leverage. Real Estate Economics, 45(2), 452-477. https://doi.org/10.1111/1540-6229.12153

Kumar, A. (2009). Who gambles in the stock market? The Journal of Finance, 64(4), 1889-1933. https://doi.org/10.1111/j.1540-6261.2009.01483.x

Lin, C. Y., Rahman, H., \& Yung, K. (2009). Investor sentiment and REIT returns. The Journal of Real Estate Finance and Economics, 39(4), 450-471. https://doi.org/10.1007/s11146-008-9115-5

Ling, D. C., Ooi, J. T. L., \& Xu, R. (2019). Asset growth and stock performance: evidence from REITs. Real Estate Economics, 47(3), 884-927. https://doi.org/10.1111/1540-6229.12186

Lintner, J. (1965). Security prices, risk, and maximal gains from diversification. The Journal of Finance, 20(4), 587-615. https://doi.org/10.2307/2977249

Merton, R. C. (1974). On the pricing of corporate debt: the risk structure of interest rates. The Journal of Finance, 29(2), 449470. https://doi.org/10.2307/2978814

Newey, W. K., \& West, K. D. (1987). Hypothesis testing with efficient method of moments estimation. International Economic Review, 28(3), 777-787. https://doi.org/10.2307/2526578

Novy-Marx, R., \& Velikov, M. (2015). A taxonomy of anomalies and their trading costs. Review of Financial Studies, 29(1), 104-147. https://doi.org/10.1093/rfs/hhv063

\section{Appendix}

\section{Appendix A. Number of defaults per year}

\begin{tabular}{|c|c|c|c|}
\hline Year & Active equity REITs & Defaulted & Default Rate \\
\hline 1990 & 38 & 1 & $7.14 \%$ \\
\hline 1991 & 42 & 0 & $0.00 \%$ \\
\hline 1992 & 49 & 2 & $5.71 \%$ \\
\hline 1993 & 84 & 1 & $2.63 \%$ \\
\hline 1994 & 111 & 0 & $0.00 \%$ \\
\hline 1995 & 120 & 1 & $1.10 \%$ \\
\hline 1996 & 131 & 1 & $1.00 \%$ \\
\hline 1997 & 164 & 0 & $0.00 \%$ \\
\hline 1998 & 195 & 3 & $1.96 \%$ \\
\hline 1999 & 194 & 4 & $2.38 \%$ \\
\hline 2000 & 188 & 1 & $0.58 \%$ \\
\hline 2001 & 194 & 1 & $0.57 \%$ \\
\hline 2002 & 175 & 3 & $1.91 \%$ \\
\hline 2003 & 177 & 0 & $0.00 \%$ \\
\hline 2004 & 201 & 0 & $0.00 \%$ \\
\hline 2005 & 201 & 0 & $0.00 \%$ \\
\hline 2006 & 204 & 0 & $0.00 \%$ \\
\hline 2007 & 174 & 3 & $2.00 \%$ \\
\hline 2008 & 148 & 5 & $3.68 \%$ \\
\hline 2009 & 147 & 6 & $4.72 \%$ \\
\hline 2010 & 148 & 1 & $0.76 \%$ \\
\hline 2011 & 159 & 0 & $0.00 \%$ \\
\hline 2012 & 166 & 0 & $0.00 \%$ \\
\hline 2013 & 187 & 0 & $0.00 \%$ \\
\hline 2014 & 187 & 0 & $0.00 \%$ \\
\hline 2015 & 204 & 0 & $0.00 \%$ \\
\hline 2016 & 211 & 0 & $0.00 \%$ \\
\hline
\end{tabular}

Ooi, J. T. L., Wang, J., \& Webb, J. R. (2009). Idiosyncratic risk and REIT returns. The Journal of Real Estate Finance and Economics, 38(4), 420-442.

https://doi.org/10.1007/s11146-007-9091-1

Pástor, L., \& Stambaugh, R. F. (2003). Liquidity risk and expected stock returns. Journal of Political Economy, 111(3), 642-685. https://doi.org/10.1086/374184

Sharpe, W. F. (1964). Capital asset prices: a theory of market equilibrium under conditions of risk. The Journal of Finance, 19(3), 425-442. https://doi.org/10.2307/2977928

Stambaugh, R. F., Yu, J., \& Yuan, Y. (2015). Arbitrage asymmetry and the idiosyncratic volatility puzzle. The Journal of Finance, 70(5), 1903-1948. https://doi.org/10.1111/jofi.12286

Sun, L., Titman, S. D., \& Twite, G. J. (2015). REIT and commercial real estate returns: a postmortem of the financial crisis. Real Estate Economics, 43(1), 8-36. https://doi.org/10.1111/1540-6229.12055

Vassalou, M., \& Xing, Y. (2004). Default risk in equity returns. The Journal of Finance, 59(2), 831-868. https://doi.org/10.1111/j.1540-6261.2004.00650.x

Zhang, A. J. (2012). Distress risk premia in expected stock and bond returns. Journal of Banking \& Finance, 36(1), 225-238. https://doi.org/10.1016/j.jbankfin.2011.07.007 


\section{Appendix B. Variable description}

\begin{tabular}{|c|c|}
\hline Variable & Definition \\
\hline Distance-to-default (DD) & $\begin{array}{l}\text { The distance of the expected value of firm's asset to the default point. High DD implies low likelihood } \\
\text { of default. DD is constructed following Bharath and Shumway (2008) }\end{array}$ \\
\hline $\mathrm{ME}$ & $\begin{array}{l}\text { The market value of equity (ME) is the product of equity REIT's price and common shares outstanding } \\
\text { (in million US dollars) at the end of June in year } t\end{array}$ \\
\hline $\mathrm{BM}$ & $\begin{array}{l}\text { The book-to-market (BM) equity ratio is calculated strictly following Davis et al. (2000) that is the } \\
\text { fiscal year-end book value of equity in the } t-1 \text { year divided by the market value of equity at the end of } \\
\text { December in } t-1 \text { year. Depending on the availability, book value of equity is defined as shareholder's } \\
\text { equity (measured in the order depending on the availability: Compustat SEQ, Compustat CEQ + } \\
\text { PSTK, or Compustat AT-LT) plus balance sheet deferred taxes and investment tax credit (Compustat } \\
\text { TXDITC, if available), minus the book value of preferred stock (measured in the order depending on } \\
\text { the availability: Compustat PSTKRV, Compustat PSTKL or Compustat PSTK) }\end{array}$ \\
\hline AG & $\begin{array}{l}\text { Asset growth (AG) is defined as the difference of Firm's total asset (Compustat AT) in fiscal year } t-1 \\
\text { and } t-2 \text {, scaled by the } t-2 \text { total assets }\end{array}$ \\
\hline Beta & $\begin{array}{l}\text { The five-year CAPM beta (Beta) is estimated as Fama and French (1996). A REIT's monthly return in } \\
\text { excess of one-month US treasury bill rate is regressed by the value-weighted excess return of CRSP } \\
\text { index in the given month: } \\
\qquad R_{i, t}-r_{f, t}=\alpha_{i, t}+\beta_{C A P M, t}\left(R_{m, t}-r_{f, t}\right)+\varepsilon_{i, t} \\
\text { The coefficient of market excess return is the monthly CAPM beta for the REIT. We take a rolling } \\
\text { window at } 60 \text { months to obtain the averaged value of five-year } \beta_{C A P M} \text {, and a minimum of } 36 \text { months } \\
\text { with non-missing value for conducting regressions is required. If the valid monthly return is less than } \\
36 \text { months in the rolling window, the } \beta_{C A P M} \text { is set as missing }\end{array}$ \\
\hline IVOL & $\begin{array}{l}\text { Idiosyncratic volatility (IVOL) is measured as Ang et al. (2006). For every month } t \text {, stock's daily } \\
\text { excess return at day } \tau \text { is regressed by daily market excess return }\left(R_{m, \tau}-r_{f, \tau}\right) \text {, size factor }(S M B) \text {, } \\
\text { value factor }(H M L) \text {. } \\
\qquad R_{i, \tau}-r_{f, \tau}=\alpha_{i, \tau}+\beta_{M K T, i}\left(R_{m, \tau}-r_{f, \tau}\right)+\beta_{S M B, i} S M B_{\tau}+\beta_{H M L, i} H M L_{\tau}+\varepsilon_{i, \tau} \text {. } \\
\text { The standard deviation of the residual }\left(\varepsilon_{i, \tau}\right) \text { of the regression is the monthly idiosyncratic volatility, } \\
\text { which is equivalent to the "1/0/1" idiosyncratic volatility reported in Ang et al. (2006). } \\
\qquad I V O L_{i, t}=\sqrt[2]{\frac{1}{N} \sum_{\tau=1}^{N} \varepsilon_{i, \tau}^{2}} \\
\text { We require returns from over } 15 \text { trading day }(N \geq 15) \text { in each month to estimate the monthly } I V O L \text {. } \\
\text { If an equity REIT has } 14 \text { or less trading days, the corresponding monthly } I V O L \text { is set as missing }\end{array}$ \\
\hline $\begin{array}{l}\text { Campbell et al.'s (2008) } \\
\text { failure probability }\end{array}$ & $\begin{array}{l}\text { Campbell et al. (2008) document a measurement of failure probability that has strong predictive power } \\
\text { in identifying default events. The measure is by taking the following two-step estimation: } \\
\qquad F P_{i, t}^{\text {score }}=-9.164-20.264 \times N I M T A A V G_{i, t}+1.416 \times T L M T A_{i, t}-7.129 \times E X R E T A V G_{i, t}+1.411 \times \\
\qquad S I G M A_{i, t}-0.045 \times R S I Z E_{i, t}-2.132 \times C A S H M T A_{i, t}+0.075 \times M B_{i, t}-0.058 \times P R I C E_{i, t} \text {. } \\
\text { The definition of the seven explanatory variables is described in Campbell et al. (2008) in detail. The } \\
\text { probability of a firm is failing in the next period is equivalent to } \\
\qquad F P_{i, t}=\frac{1}{1+\mathrm{e}^{-F P_{i, t}^{\text {score }}}}\end{array}$ \\
\hline
\end{tabular}




\section{Appendix C. Robustness check for default risk premium}

\begin{tabular}{|c|c|c|c|c|}
\hline $\begin{array}{l}\text { Mean Excess } \\
\text { Return }\end{array}$ & CAPM Alpha & FF-3 Alpha & FFC Alpha & FF-5 Alpha \\
\hline \multicolumn{5}{|c|}{ Panel A: Full sample } \\
\hline 1.168 & 1.468 & 1.653 & 1.142 & 1.451 \\
\hline$(2.17)$ & $(2.95)$ & $(3.56)$ & $(2.45)$ & $(2.66)$ \\
\hline \multicolumn{5}{|c|}{ Panel B: Drop \$1 REITs } \\
\hline 0.998 & 1.316 & 1.569 & 1.102 & 1.391 \\
\hline$(1.99)$ & $(2.87)$ & $(3.77)$ & $(2.61)$ & $(2.84)$ \\
\hline \multicolumn{5}{|c|}{ Panel C: Monthly rebalance } \\
\hline 1.012 & 1.328 & 1.566 & 1.111 & 1.450 \\
\hline$(1.91)$ & $(2.83)$ & $(3.61)$ & $(2.37)$ & $(3.22)$ \\
\hline \multicolumn{5}{|c|}{ Panel D: Rebalance on January every year } \\
\hline 0.584 & 0.862 & 1.046 & 0.530 & 0.836 \\
\hline$(1.15)$ & $(1.94)$ & $(2.58)$ & $(1.61)$ & $(1.85)$ \\
\hline \multicolumn{5}{|c|}{ Panel E: Feng et al. (2011) list } \\
\hline 0.390 & 0.793 & 0.991 & 0.683 & 0.864 \\
\hline$(0.76)$ & $(1.73)$ & $(2.37)$ & $(1.41)$ & $(1.95)$ \\
\hline \multicolumn{5}{|c|}{ Panel F: Equally weighted } \\
\hline 0.320 & 0.632 & 0.869 & 0.467 & 0.739 \\
\hline$(0.68)$ & $(1.47)$ & $(2.37)$ & $(1.17)$ & $(1.73)$ \\
\hline \multicolumn{5}{|c|}{ Panel G: Campbell et al. (2008) failure probability } \\
\hline 1.068 & 1.425 & 1.586 & 1.254 & 1.243 \\
\hline$(2.20)$ & $(3.02)$ & $(3.41)$ & $(2.53)$ & $(2.59)$ \\
\hline
\end{tabular}

Note: The table reports robustness check for default risk premium. Panel A reports the excess return and abnormal returns on the portfolios by using the full sample. Panel B reports the excess return and abnormal returns on the portfolios by using the sample excluding stocks with price below $\$ 1$. Panel $\mathrm{C}$ reports the excess return and abnormal returns on the portfolios which are monthly rebalanced. Panel D reports the excess return and abnormal returns on the portfolios which are rebalanced in January. Panel E reports the excess return and abnormal returns on the portfolios by using the sample of REITs list of Feng et al. (2011). Panel F reports the value-weighted excess return and abnormal returns on the portfolios. Panel $\mathrm{G}$ reports the excess return and abnormal returns on the portfolios according to the failure probability of Campbell et al. (2008). The monthly average abnormal returns on portfolios are computed relative to the capital asset pricing model (CAPM) of Sharpe (1964) and Lintner (1965), the Fama and French (1993) three-factor (FF-3) model, the Fama and French (1993) and Carhart (1997) four-factor (FFC) model, and the Fama and French (2015) fivefactor (FF-5) model. The period is from January 1990 to December 2016. 